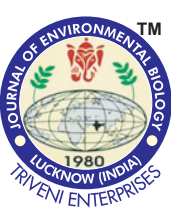

\title{
Quality traits of low-sodium fish balls incorporated with barley flour and pea flour
}

\section{Authors Info}

\section{L.A. Ganie, A. Kumar* and T. Tanwar}

Division of Livestock Products Technology, Faculty of Veterinary Sciences and Animal Husbandry, Sher-e-Kashmir University of Agricultural Sciences and Technology of Jammu, R.S. Pura-181 102, India

*Corresponding Author Email : drarvindlpt@gmail.com

\section{Key words}

Barley flour,

Fish balls,

Pea flour,

Quality attributes,

Storage quality

\section{Publication Info}

Paper received : 08.06.2016

Revised received : 28.10 .2016

Re-revised received : 24.12 .2016

Accepted : 26.12 .2016

\section{Abstract}

Aim: The present study was conducted to analyze the effect of fortification of various variants and combinations of barley flour and pea flour on the quality traits of fish balls.

Methodology: The technical programme was formulated to evaluate and assess the quality traits of low sodium fish balls incorporated with barley and pea flour. The product was developed by replacing ten percent of lean fish flesh (wt/wt) with three different variants and combination of barley flour and pea flour in the following ratios: $20: 25,50: 50$ and $75: 25$. The control samples were prepared by incorporating $10 \%$ refined wheat flour (wt/wt). The prepared designer emulsion based fish products were packaged hygienically under aerobic condition in 100 gauge polyethylene pouches. All the prepared products were examined for various storage quality traits in refrigerated $\left(4 \pm 1^{\circ} \mathrm{C}\right)$ condition for 21 days at weekly intervals.

Results: The physico-chemical quality, emulsion uniformity and stability and uniformity, cooking yield and sensory attributes were found to be significantly $(p<0.05)$ higher with low sodium fish ball product fortified with barley flour and pea flour in 25:75 ratio was optimum and suitable for the preparation of fish balls. The FFA, TBARS and all the microbiological profile were found to be significantly $(p<0.05)$ inclined with the successive storage days.

Interpretation: Low sodium fish balls can be optimally and suitably prepared with barley flour and pea flour in $25: 75$ ratio with substitution of $10 \%$ of lean fish meat (wt/wt). The developed products were found to be safe and fit for human consumption till $14^{\text {th }}$ day of refrigeration storage, without adversely affecting any of its sensory qualities.

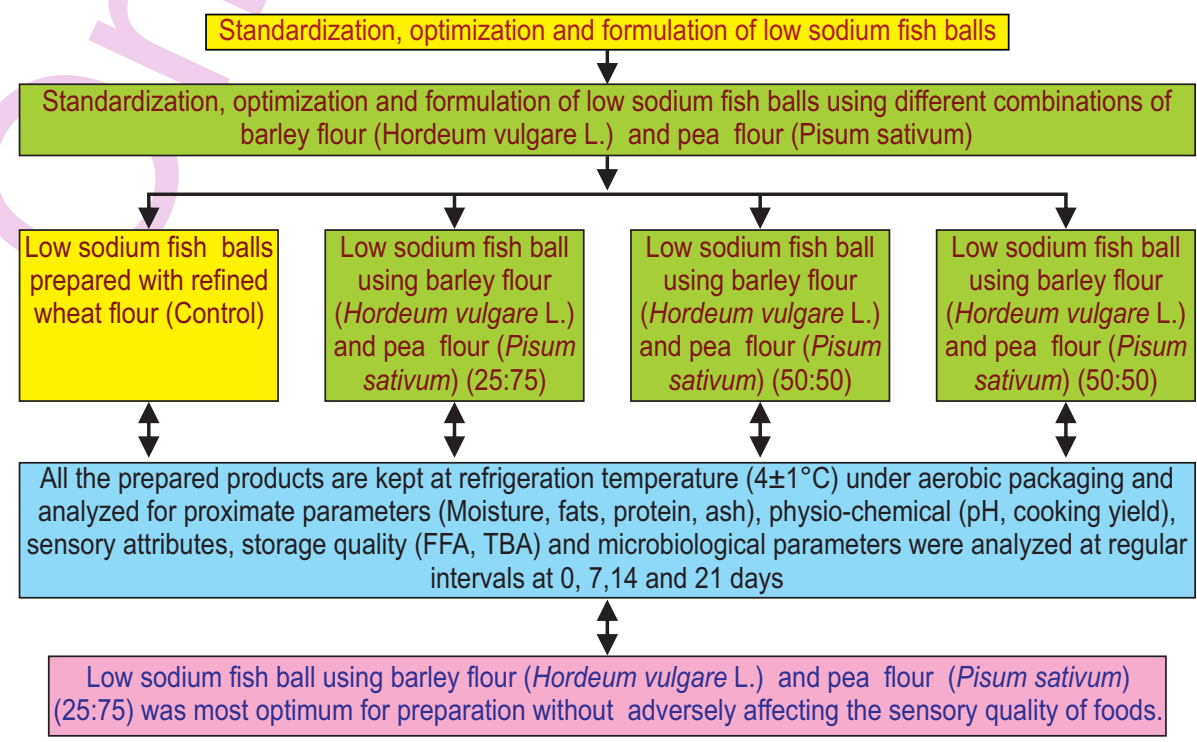




\section{Introduction}

Fish provides one of the best sources of high quality animal protein with high biological value. Fish has several important nutritional characteristics which has potential health benefits as compared to other meat. It's cholesterol content is low but it is quite high in mono and polyunsaturated fatty acids good for heart and brain (FAO, 2014). In recent years, due to health awareness and urbanization, the consumers prefer fast and health food. Several studies have been carried out by food scientists about the production and their quality stability of the fisheries fast food products (Paramasivam et al., 2007). The extenders and fillers are non-meat products with substantial protein and carbohydrate content. The use of extenders and fillers add bulk to fish product thereby reducing the production cost three times approximately (Heinz and Hautzinger, 2007). Barley (Hordeum vulgare) can be used as cereal based extender and fillers. They are natural source of fiber, maltose, selenium, tryptophan and phosphorus. Barley contains high amount of dietary fiber especially beta-glucan which helps to lower cholesterol by reducing glycemic index and also acts as probiotics. It contains magnesium, which directly affects the amount of glucose and insulin produced and released in the body. Green peas (Pisum sativum) can be a useful source of pulse based extender as it contain coumestrol. It is one of the most nutritious legume with health benefiting organic components. It is an excellent source of folates, indispensable for intracellular DNA synthesis. It also contain phytosterols, especially $\beta$-sitosterol that reduces cholesterol level in the body (Martelo-Vidal, et al., 2012). Thus, the objective of the present study was to develop a ready to eat functional fish food, utilizing barley and pea flour as extender and binder.

\section{Materials and Methods}

Preparation of fish balls : Spineless flesh of Pangasius pangasius a fish belonging to family, Pangasidae was used in the formulation and preparation of fish balls. The procedure for its preparation was carried out in the following steps: preparation of uniform emulsion, filling in manual ball shaped extruder, cooking of fish balls as deep fat frying. After removing mid-spine, fish flesh was cut into smaller pieces and minced in a mincer. Low sodium fish balls were prepared as per following formulation: fish flesh$59.70 \mathrm{~g}$, ice flakes- $10.0 \mathrm{~g}$, condiments- $5.0 \mathrm{~g}$, vegetable oil- $9.0 \mathrm{~g}$, wheat flour-10.0 g, spice- $2.50 \mathrm{~g}, \mathrm{NaCl}+\mathrm{KCl}+$ citric acid+sucrose$1.0+0.5+0.25+0.25$ (low sodium salt combination), STPP- 0.30 gm, MSG-0.50 g and egg white-1.00 g. Uniform fish emulsion was prepared in a bowl chopper by adding all the curing ingredients, spice mixture, condiments and finally chopped for 4.0 mins. A $100.0 \mathrm{~g}$ of the above emulsion was fed into a spherical extruder of diameter $2.5 \mathrm{~cm}$ to obtain fish balls of uniform shape and size, which was deep fat fried at $180 \pm 5^{\circ} \mathrm{C}$ for 5.0 mins. Control fish balls and treated fish balls were prepared by replacing $10 \%$ of lean fish flesh by $75: 25,50: 50$ and $25: 75$ combination levels of barley flour and pea flour. The number of samples analyzed for quality traits was six and for sensory analysis were twenty one. Out of all the low sodium fish balls prepared with various combinations of flours, the best combinations of flours among these had adjudged on its quality traits and then further the selected best treatment and control were studied to check out its storage-life based on storage quality profile of the developed designer value added fish products.

Analytical analyses: Emulsion stability was calculated as described by Townsend et al. (1968). The pH of designer fish ball was estimated by the method of Keller et al. (1974). Proximate composition was estimated as per AOAC (2000). Free fatty acid values were determined as per Koniecko (1979). TBARS value was calculated as per Witte et al. (1970). Sensory evaluation was carried out as per Seman et al. (1987). Microbiological quality profile was computed as per APHA (2015). Statistical analysis was calculated and computed as per Snedecor and Cochran (1997) methods.

\section{Results and Discussion}

Table 1 depicts the physico-chemical and proximate composition of control and treated fish balls prepared with various combinations of barley and pea flours. The emulsion stability was highest for fish balls prepared by incorporating barley flour with pea flour in 25:75 ratio and differed significantly from emulsion stability of fish balls prepared by fortifying other combinations of barley with pea flour, as well as control fish balls. Increase in emulsion stability of fish ball with incorporation of flours could be possibly attributed to higher moisture holding property of flour used in the preparation of fish balls. Cooking yield was highest for fish balls prepared by incorporating barley with pea flour in 25:75 ratio and differed significantly $(p<0.05)$ from other variants, as well as control fish balls. This might be probably due to higher moisture and fat retention capacity of fish balls prepared with barley and pea flour. In a previous study cooking yield was reported to enhance with increase in the level of leguminous flour, used as extenders in emulsion meat (kababs) products (Bhat and Pathak, 2011; Kumar et al., 2007).

The $\mathrm{pH}$ of low sodium fish balls increased gradually with inclination in level of fortification of barley flour and decreased with addition of pea flour in the formulation. The $\mathrm{pH}$ change with flour level might be due to neutral and basic nature of flour used in preparation of value added fishery product. Similar findings were observed in meat products extended with other legume flours which may be attributed to the fact that flours do have higher and static pH in comparison to fish flesh (Kumar et al., 2007; Bhat and Pathak, 2011).

Moisture and protein content was highest for low sodium fish balls prepared by incorporating barley flour with pea flour in $75: 25$ ratio and differed significantly $(p<0.05)$ from fish balls 
Table 1 : Effect of different combinations of barley flour and pea flour on $\mathrm{pH}$, emulsion stability, cooking yield and proximate composition of low sodium fish balls

\begin{tabular}{lcccc}
\hline Parameters & \multicolumn{4}{c}{ Levels of barley flour and pea flour } \\
\cline { 2 - 5 } & $\mathbf{0}$ & $\mathbf{2 5 : 7 5}$ & $\mathbf{5 0 : 5 0}$ & $\mathbf{7 5 : 2 5}$ \\
\hline $\mathrm{pH}$ & $5.76 \pm 0.13^{\mathrm{a}}$ & $5.97 \pm 0.25^{\mathrm{a}}$ & $5.71 \pm 0.35^{\mathrm{a}}$ & $6.12 \pm 0.36^{\mathrm{a}}$ \\
Emulsion stability & $82.58 \pm 0.53^{\mathrm{a}}$ & $86.67 \pm 0.31^{\mathrm{c}}$ & $85.18 \pm 0.45^{\mathrm{b}}$ & $85.19 \pm 0.34^{\mathrm{b}}$ \\
Moisture (\%) & $58.01 \pm 0.84^{\mathrm{a}}$ & $58.04 \pm 0.99^{\mathrm{a}}$ & $58.31 \pm 0.64^{\mathrm{a}}$ & $59.08 \pm 0.70^{\mathrm{a}}$ \\
Protein (\%) & $20.44 \pm 0.60^{\mathrm{a}}$ & $20.75 \pm 0.55^{\mathrm{a}}$ & $20.78 \pm 0.56^{\mathrm{a}}$ & $21.09 \pm 0.79^{\mathrm{a}}$ \\
Fat (\%) & $10.76 \pm 0.32^{\mathrm{a}}$ & $10.53 \pm 0.32^{\mathrm{a}}$ & $10.39 \pm 0.27^{\mathrm{a}}$ & $10.55 \pm 0.30^{\mathrm{a}}$ \\
Ash (\%) & $3.81 \pm 0.18^{\mathrm{a}}$ & $4.17 \pm 0.29^{\mathrm{a}}$ & $4.28 \pm 0.33^{\mathrm{a}}$ & $4.57 \pm 0.37^{\mathrm{a}}$ \\
Cooking yield & $81.73 \pm 0.60^{\mathrm{a}}$ & $85.09 \pm 0.48^{\mathrm{c}}$ & $84.26 \pm 0.42^{\mathrm{ab}^{\mathrm{b}}}$ & $83.45 \pm 0.43^{\mathrm{ab}}$ \\
\hline
\end{tabular}

Mean \pm SE with different superscripts in a row differs significantly $(p<0.05) . n=6$

Table 2 : Effect of different combinations of barley flour and pea bean flour on sensory attributes of low sodium fish balls

\begin{tabular}{lllll}
\hline Sensory attributes & \multicolumn{4}{l}{ Levels of barley flour and pea flour } \\
\cline { 2 - 4 } & $\mathbf{0}$ & $\mathbf{2 5 : 7 5}$ & $\mathbf{5 0 : 5 0}$ & $\mathbf{7 5 : 2 5}$ \\
\hline Appearance & $6.02 \pm 0.297^{\mathrm{a}}$ & $6.67 \pm 0.193^{\mathrm{a}}$ & $6.18 \pm 0.301^{\mathrm{a}}$ & $6.13 \pm 0.204^{\mathrm{a}}$ \\
Flavour & $6.38 \pm 0.269^{\mathrm{ab}}$ & $6.90 \pm 0.142^{\mathrm{b}}$ & $6.04 \pm 0.210^{\mathrm{a}}$ & $6.09 \pm 0.199^{\mathrm{a}}$ \\
Juiciness & $6.58 \pm 0.221^{\mathrm{a}}$ & $7.01 \pm 0.195^{\mathrm{a}}$ & $6.33 \pm 0.240^{\mathrm{a}}$ & $6.51 \pm 0.234^{\mathrm{a}}$ \\
Texture & $6.23 \pm 0.159^{\mathrm{a}}$ & $6.99 \pm 0.094^{\mathrm{b}}$ & $6.41 \pm 0.199^{\mathrm{ab}}$ & $6.56 \pm 0.294^{\mathrm{ab}}$ \\
Overall acceptability & $6.16 \pm 0.152^{\mathrm{a}}$ & $7.06 \pm 0.095^{\mathrm{b}}$ & $6.15 \pm 0.113^{\mathrm{a}}$ & $6.25 \pm 0.082^{\mathrm{a}}$
\end{tabular}

Mean $\pm S E$ with different superscripts in a row differs significantly $(P<0.05)$. Mean values are scores on 8 point descriptive scale where 1-extremely poor and 8 - extremely desirable. $n=21$ for each treatment

prepared with other combination of flours, as well as control fish balls. Enhanced moisture content might be due to better moisture retention potency of flours used in the formulation. The higher protein content was probably due to higher level of pea flour used in fish ball preparation. There was a gradual decline in fat content of low sodium fish balls prepared by fortification of different variants and combinations of barley flour with pea flour but was comparable to control fish balls. This decrease noted in treated fish ball was probably due to lower fat absorption and retention potential upon frying as compared to lean fish flesh. Ash content was highest in fish balls prepared by fortification barley flour and pea flour in 75:25 ratio and varied significantly $(p<0.05)$ from control fish balls. This could be attributed to higher ash content of barley flour used in value added fish balls formulation.

Table 2 presented sensory characteristics of fish ball prepared with various variants and combinations of barley and pea flour. Color and appearance score of the products ranked highest at flour fortification ratio of 25:75, although comparable to control fish balls as well to other variants of treated fish balls. This decline in the appearance and colour was probably attributed to browning of treated fish products with exposure to heat. Similar results were concluded in value added chicken meat balls, where sensory panel ranked higher to the lighter color of products (Chandralekha et al., 2012). Flavor was given highest scores for low sodium fish balls treated with barley flour with pea flour in $25: 75$ ratio. It also significantly $(p<0.05)$ differed from flavor ranks of fish balls treated with other combinations of flour, as well as control fish balls. The flavor ranking declined as the level of flour increased in fish ball formulation. The decrease in flavor was probably due to decline in meaty flavor with increase in flour level in the treated products. Similar results were observed by (Chandralekha et al., 2012) in value addition of poultry meat balls with incorporation of soy flour and corn flour. Similar findings in flavour points of legume flours extended meat products were reported Bhat and Pathak (2011) and Kumar et al. (2007). Juiciness was highest at twenty five is to seventy five ratio treated fish ball comparable to control as well to fish balls prepared by incorporating other variants and combination of flours. This might be due to the fact that the treated products bound more water and retain them than other variants and combination levels of flours used in formulation and preparation of value added fish products. Similar results were published in frozen restructured steaks made of poultry meat (Bhoyar et al., 1996) and frozen low fat meat balls of beef (Serdaroglu et al., 2004), which further strengthened the results of the present study. Texture ranked highest in 25:75 ratio flour and varied significantly $(p<0.05)$ from control fish balls, as well as fish balls prepared by different combinations of barley and pea flour. The higher score values of overall acceptability might be due to higher scores for other sensory attributes for the 
Table 3 : Effect of refrigerated temperature storage on physico-chemical characteristics of aerobically packaged low sodium fish balls incorporated with $10 \%$ refined wheat flour and $25: 75$ barley flour with pea flour combinations

\begin{tabular}{|c|c|c|c|c|}
\hline \multirow[t]{2}{*}{ Treatment } & \multicolumn{4}{|c|}{ Storage period in days } \\
\hline & 0 & 7 & 14 & 21 \\
\hline \multicolumn{5}{|l|}{$\overline{\mathrm{pH}}$} \\
\hline RWF & $6.07 \pm 0.18^{\mathrm{Aa}}$ & $6.06 \pm 0.23^{\text {Aa }}$ & $5.78 \pm 0.17^{\text {Aa }}$ & $5.99 \pm 0.16^{\text {Aa }}$ \\
\hline $\mathrm{BP}$ & $6.20 \pm 0.16^{\mathrm{Aa}}$ & $5.93 \pm 0.15^{\mathrm{Aa}}$ & $5.75 \pm 0.22^{\text {Aa }}$ & $5.71 \pm 0.17^{\text {Aa }}$ \\
\hline \multicolumn{5}{|c|}{ TBARS (mg malonaldehyde $\mathrm{kg}^{-1}$ ) } \\
\hline RWF & $0.40 \pm 0.21^{\mathrm{Aa}}$ & $0.45 \pm 0.24^{\mathrm{Aa}}$ & $0.64 \pm 0.20^{A b}$ & $0.71 \pm 0.17^{\mathrm{Ac}}$ \\
\hline $\mathrm{BP}$ & $0.45 \pm 0.02^{\mathrm{Aa}}$ & $0.62 \pm 0.02^{\mathrm{cb}}$ & $0.71 \pm 0.02^{\mathrm{BC}}$ & $0.80 \pm 0.02^{\mathrm{Bd}}$ \\
\hline \multicolumn{5}{|c|}{ FFA $(\%$ oleic acid $)$} \\
\hline RWF & $0.090 \pm 0.007^{\mathrm{Aa}}$ & $0.131 \pm 0.003^{A b}$ & $0.233 \pm .005^{\mathrm{Ac}}$ & $0.388 \pm 0.009^{\mathrm{Ad}}$ \\
\hline BP & $0.115 \pm 0.004^{\mathrm{Ba}}$ & $0.138 \pm 0.006^{\mathrm{Aa}}$ & $0.240 \pm 0.007^{\mathrm{Ab}}$ & $0.351 \pm 0.013^{\mathrm{Ac}}$ \\
\hline \multicolumn{5}{|c|}{ Total plate count $\left(\log \mathrm{cfu}^{-1}\right)$} \\
\hline RWF & $2.37 \pm 0.05^{\mathrm{Aa}}$ & $2.62 \pm 0.06^{\mathrm{Aa}}$ & $3.31 \pm 0.11^{\mathrm{Ab}}$ & $4.17 \pm 0.21^{\mathrm{Ac}}$ \\
\hline $\mathrm{BP}$ & $2.30 \pm 0.04^{\mathrm{Aa}}$ & $2.80 \pm 0.06^{\mathrm{Bb}}$ & $3.50 \pm 0.05^{\mathrm{Ac}}$ & $4.61 \pm 0.06^{\mathrm{Ad}}$ \\
\hline \multicolumn{5}{|c|}{ Psychrotrophic count (log cfu g $\left.{ }^{-1}\right)$} \\
\hline RWF & ND & ND & $2.24 \pm 0.04^{A b}$ & $3.35 \pm 0.26^{\mathrm{Ac}}$ \\
\hline BP & ND & ND & $2.56 \pm 0.20^{\mathrm{Ab}}$ & $3.85 \pm 0.21^{A c}$ \\
\hline \multicolumn{5}{|c|}{ Coliform count (log cfu g $\left.{ }^{-1}\right)$} \\
\hline RWF & ND & ND & ND & $2.63 \pm 0.13^{\mathrm{Ab}}$ \\
\hline $\mathrm{BP}$ & ND & ND & ND & $3.53 \pm 0.06^{\mathrm{Bb}}$ \\
\hline \multicolumn{5}{|c|}{ Yeast and Mould count (log cfu g $\left.{ }^{-1}\right)$} \\
\hline RWF & ND & ND & ND & $2.40 \pm 0.22^{A b}$ \\
\hline $\mathrm{BP}$ & ND & ND & ND & $2.64 \pm 0.24^{\mathrm{Ab}}$ \\
\hline
\end{tabular}

Mean \pm SE with different superscripts in a row wise (lower case alphabet) and column wise (upper case alphabet) differ significantly $(p<0.05)$.RWF=Refined wheat flour (control), BP=Barley and peanut flour

formulation 25:75 ratio of barley and pea flour as compared to control and other combination of fish balls. Hence, $25: 75$ ratio of barley and pea flour fortified low sodium fish balls was found best, most suitable and optimum for emulsion based low sodium fish ball preparation. Based on the outcome of various quality traits viz. cooking yield, emulsion stability and sensory evaluation, the low sodium fish balls prepared by treating 25:75 ratio of barley and pea flour were selected for storage quality analysis and were evaluated.

The prepared value added fish products were packaged hygienically under aerobic condition in 100 gauge polyethylene pouches and tested for their storage quality parameter profiles at weekly intervals and their results is tabulated in Table 3.

The treated fish product for storage study had a significant $(p<0.05)$ reducing effect on the $\mathrm{pH}$ value, which might be due to nutrients present in the product and their easy microbial degradation to form lactic acid. The $\mathrm{pH}$ of Daucus carrota fortified poultry meat nuggets reduced significantly with successive storage days (Devatkal et al., 2008). However, the findings were in contrast to those resulted on low fat Turkish type meat balls by (Bingol et al., 2010). The FFA showed a significant $(p<0.05)$ increasing trend on $14^{\text {th }}$ day onwards successive storage days. A significant $(p<0.05)$ increase in FFA content during storage might be due to time, temperature and moisture content and exposure to various environmental conditions such as storage, processing etc. (Das et al., 2008). The FFA content was also reportedly enhanced in chicken meat fed with diet containing cinnamon powder during successive storage days under refrigeration (Sang-Ohetal., 2013). TBA showed significant $(p<0.05)$ increasing trend from $14^{\text {th }}$ day onwards during storage at refrigeration temperature. The increase in TBA values on storage might be due to oxidation and peroxidation of lipids and fats present in the products that resulted in the formation of malondialdehyde. A general increasing trend of TBA value during refrigerated and frozen storage of Daucus carrota fortified chicken nuggets has been reported earlier Devatkal et al. (2008); Ratanatriwong et al. (2010) and Singh et al. (2011). The TBA value of chicken meat fed with cinnamon was reported to increase on progressive storage days (Sang-Oh et al., 2013).

The mean microbial count profile of low sodium control and treated fish balls were evaluated and found elevated significantly $(p<0.05)$ on all progressive storage days in control and treated fish balls. Similar results were also published by Siddique et al. (2013) while experimenting on quality and shelf life of fish products prepared from Bombay duck. Similar conclusion was drawn by Kumar et al. (2007) in chicken meat patties. The total aerobic count reportedly increased at each successive and 
progressive storage study period in meat snacks (Singh et al., 2011; Visnuvinayagam et al., 2015). Psychrotrophs were not detected $14^{\text {th }}$ day onwards in both control and treated products, which was probably due to high temperature used in frying fish balls which crossed the thermal death point of bacteria, however they appeared at fortnight which might be due to post contamination. Moreover, most psychrotrophs have incubation period of approximately week days. The coliform count was not detected in any product till fortnight of storage, however they appeared and were counted in both control and treated products on $21^{\text {st }}$ day of storage. Appearance of coliforms fungal count in the designer products on $21^{\text {st }}$ day might be due to post contamination. Singh et al. (2011) concluded parallel while working on quality assessment of vacuum packaged chicken snacks stored at ambient temperature.

In conclusion, the developed fish ball prepared by incorporating barley flour and pea flour $(25: 75)$ resulted to be most suitable and optimal for preparation of low sodium fish balls with a profile of higher emulsion stability, cooking yield, proximate composition and sensory parameters. The developed designer low sodium fish balls were found to be safe and fit for human consumption till $14^{\text {th }}$ day kept at refrigeration storage at $\left(4 \pm 1^{\circ} \mathrm{C}\right)$.

\section{Acknowlegment}

The authors acknowledge all the technical and financial support by provided the Faculty of Veterinary Sciences and Animal Husbandry, SKUAST Jammu to carry out this research work.

\section{References}

AOAC: Official methods of analysis. $17^{\text {th }}$ Edn., Association of official Agriculture Chemists, Washington DC, USA(2000).

APHA: Compendium of methods for the microbiological examination of foods. $5^{\text {th }}$ Edn. (Ed. M.L.Speck). American Public Health Association, Washington DC, USA (2015).

Bhat, Z.F. and V. Pathak: Effect of black bean (Vigna mungo) on the quality characteristics of oven-roasted chicken seekh kababs. J. Stored Prod. Postharv. Res., 2, 15-23 (2011).

Bhoyar, A.M., N.K. Pandey, S.K. Anand and S.S. Verma: Development of restructured chicken steaks using textured soy protein as extender. Ind. Food Pack., 6, 15-22 (1996).

Bingol, S.A. and H. Kocamis: The gene expression profile by RT-PCR and immune-histochemical expression pattern of catalase in the kidney tissue of both healthy and diabetic mice. Kafkas Univ Vet FakDerg., 16, 825-834 (2010).

Chandralekha, S., J.A. Babu, P.R.S. Moorthy and B. Karthikeyan: Process optimization for the development of value added chicken meatballs. Tam. J. Vet.Ani. Sci., 8, 176-180 (2012).

Das, A.K., A.S.R. Anjaneyulu, Y.P. Gadekar, R.P. Singh and H. Pragati: Effect of full-fat soy paste and textured soy granules on quality and shelf-life of goat meat nuggets in frozen storage. Meat Sci., 80, 607-614 (2008).
Devatkal, S.K., S. Sivakumar, A.K. Biswas, J. Sahoo, M.K. Chatli and S. Balasumaramanian: Evaluation of instrumental texture, colour and sensory qualities of chicken nuggets prepared with ground carrot. Ind. J. Poult. Sci., 43, 369-370 (2008).

FAO: Fishery Technology Fisheries and aquaculture fact sheet. http://www.fao.org/ fishery/topic/2800/en (2014)

Heinz, G. and P. Hautzinger: Meat processing technology for Small to medium-Scale Producers. Food and Agricultural Organization, ISBN: 978-974-7946-99. (2007).

Keller, J.E., G.C. Skelley and J.C. Acton: Effect of meat particle size and casing diameter on summer sausage properties. J. Milk Food Tech., 37, 297-300 (1974).

Koniecko, E.S.: Handbook for Meat Chemists. Avery Publishing Group Inc., Wayne New Jersey, pp. 53-55 (1979).

Kumar, R.R., B.D. Sharma, M. Kumar, Chidanandaiah and A.K. Biswas: Storage quality and shelf life of vacuum-packaged extended chicken patties. J. Musc. Food., 18, 253-263 (2007).

Martelo-Vidal, M.J., J.M. Mesas and M. Vazquez: Low-salt restructured fish products from Atlantic mackerel (Scomber scombrus) with texture resembling turkey breast. Food Sci. Technol. Int., 18, 251259 (2012).

Paramasivam, S., T. Thangaradjou and L. Kannan: Effect of natural preservatives on the growth of histamine producing bacteria. $\mathrm{J}$. Environ. Biol., 28, 271-274 (2007).

Sang-Oh, P., R. Chae-Min, P. Byung-Sung and H. Jong: The meat quality and growth performance in broiler chicken fed diet with cinnamon powder. J. Environ. Biol.,34, 127-133 (2013).

Seman, D.L., W.G. Mody, J.D. Fox and N. Gay: Influence of hot and cold deboning on the palatability, structure and economic trait of restructured beef steek. J. Food Sci., 52, 879-882 (1987).

Serdaroglu, M. and O. Degirmencioglu: Effects of fat level $(5 \%, 10 \%$, $20 \%$ ) and corn flour $(0 \%, 2 \%, 4 \%)$ on some properties of Turkish type meatballs (koefte). Meat Sci., 68, 291-296 (2004).

Siddique, M.A., A.A.K.M. Nowsad, M.N. Islam, M.S. Uddin, M.A.A. Faroque and $S$. Yeasmine: Quality and shelf life of fish sausage and fish ball prepared from Bombay duck. Bangl. Res. Pub. J., 8, 41-48 (2013).

Singh, V.P., M.K. Sangyal, P.C. Dubay and S.K. Mendirtta: Quality assessment of vacuum packaged chicken snacks stored at room temperature. J. Stor. Prod. Postharv. Res., 2, 120-126 (2011).

Snedecor, G. and W. Cochran: Statistical Methods. $8^{\text {th }}$ Edn., The lowa State University Press (1997).

Townsend, W.E., L.P. Witnauer, J.A. Riloff and C.E. Swift: Comminuted meat emulsions: Differential thermal analysis of fat transition. Food Tech., 22, 319-323 (1968).

Tuomilehto, J., H. Karppanen, A. Tanskanen, J. Tikkanen and J. Vuori: Sodium and potassium excretion in a sample of normotensive and hypertensive persons in Eastern. Fin. J. Epid. Comm. Hlth., 34, 174-178(1980).

Visnuvinayagam, S., T.C. Joseph, V. Murugadas, R. Chakrabarti and K.V. Lalitha: Status on methicillin resistant and multiple drug resistant Staphylococcus aureus in fishes of Cochin and Mumbai coast, India. J. Environ. Biol., 36, 571-575 (2015)

Witte, V.C., G.F. Krause and M.E. Bailey: A new extraction method for determining 2-thiobarbituric acid value of beef during storage. J. Food Sci., 35, 582-585(1970). 